\title{
Seasonal sugarcane harvesters of Gujarat: trapped in a cycle of poverty
}

\author{
Leela Visaria $^{1} \cdot$ Harish Joshi ${ }^{1}$
}

Accepted: 15 October 2020 / Published online: 10 February 2021

(c) Institute for Social and Economic Change 2021

\begin{abstract}
Based on primary data collected from the households of Dangs district in South Gujarat, India, the paper shows that every year a third of young adults migrate to Surat district and neighbouring areas for half a year to work as sugarcane harvesters. The data show that they live in temporary shelters in harsh conditions with bare minimum necessities and amenities. A large share of their earnings, much lower than the minimum wage rate for agricultural labour, is used to pay the labour contractors who provide cash advances during the lean post-monsoon months. Paying back the principal amount with hefty interest on it traps generations of migrant workers in the vicious cycle of poverty and indebtedness.
\end{abstract}

Keywords Seasonal migration · Dangs $\cdot$ Koyta $\cdot$ Labour contractor $\cdot$ Indebtedness $\cdot$ Poverty

JEL Classification D63 · G51

\section{Introduction}

A one-way population movement both across and within countries generally occurs from less endowed areas to well-endowed prosperous areas through the 'push' created by poverty and a lack of work or employment opportunities at place of origin and the 'pull' created by better wages at the destination. On the other hand, seasonal migration of labour occurs for time-bound and seasonal economic activities that require workers only for shorter duration every year. Such migration is different from one-time linear migration. Seasonal labour movements tend to be repetitive or cyclical in nature and are often based on annual agricultural cycles. In India, seasonal migrants usually move to work on construction sites, cotton and sugarcane farms, in salt pans, stone quarries or brick-making kilns. They are compelled to move because of the lack of livelihood options and seasonal food insecurity in the areas where they live.

Given the nature of movements, estimates of the magnitude of seasonal migration in India are scanty and the limited available information is often based on inadequate data or has definitional limitations. The National Commission on Rural Labour (NCRL), on

Leela Visaria

lvisaria@gmail.com

1 GIDR, Ahmedabad, India 
the basis of the industries employing migrant workers, estimated that in 1991, there were roughly 10 million seasonal or circular migrants in rural areas alone (about $1 \%$ of total population of the country), consisting of roughly 4.5 million inter-state and 6 million intra-state migrants (Srivastva and Sasikumar 2003). Based on the number of 10 million migrants, it was assumed that 50 million people were dependent on earnings of migrant workers (assuming that the migrant is the sole earner and supports five household members on average).

The decennial censuses of India cannot provide estimates of cyclical movements of population because they are conducted only once in ten years. However, the Census information by sectors of employment does give an indication about the sectors that employ large number of informal or temporary workers, but since the data are not tabulated by the duration of employment, one cannot estimate what proportion of workers are reported as seasonal workers even as on the census date.

The 55th round of National Sample Survey Organisation (NSSO) of 1999-2000 was the first large data set to collect information from the households by asking questions on duration of migration. It defined short-duration migration as 'persons staying away from usual place of residence for 60 days or more for employment or better employment or in search of employment'. Using this definition, it estimated that about $1 \%$ of Indian population or 10 million people migrated temporarily (NSSO 2001). Although the figure was the same as that was used a decade ago, the methodology of estimating the number of seasonal or temporary migrants was different.

The 64th Round of the NSSO, conducted in 2007-2008, also provided some estimates of the magnitude and characteristics of short-term migrants (those who stayed away from their usual place of residence between one and six months in a year). It estimated that in India, as a whole 15 million people migrated seasonally. However, many believe this to be a gross underestimate. Based on estimates of informal workers employed in sectors such as construction, brick kiln, textile, garment, leather and mica industries, mines and quarries, agriculture, sugarcane harvesting and domestic work, Deshingkar and Akter (2009) estimated that there were roughly 100 million circular migrants in India in 2004-2005.

Evidently, the estimates vary widely and no precise figures seem possible. At the same time, according to a number of micro-studies seasonal migration for employment in India has been growing in terms of absolute numbers and also in relation to the size of working population as a whole (Breman 1978, 1996; Rogaly et al. 2001). Further, it has been noted that there are large inter-state variations in seasonal migration.

Based on the 64th Round NSSO data, Keshari and Bhagat (2012) calculated seasonal out-migration rate per 1000 population for major states of India and found that for the age group 15-64, it was the highest at 50 per 1000 in Bihar, 34-36 in Madhya Pradesh and Jharkhand. Surprisingly, for Gujarat, which is among the better developed states of the country, seasonal migration was 34 per 1000 population-a rate very similar to the relatively backward states. Also, most of the migration in Gujarat was rural to rural. According to some micro-level studies from Gujarat and elsewhere in India, seasonal migration from rural-to-rural areas or to cities is a survival option and a main source of income for those who have no land or have small parcel of land and thus cannot support themselves through agricultural activities. Also, most of such migrants belong to lower caste and tribal groups (Breman 1996; Deshingkar and Start 2003; Keshari and Bhagat 2012; Rao 2005a, b; Ashok and Thomas 2014).

Seasonal migration is not well documented or researched in terms of the spread and scale of its occurrence, the employer-labour relationship or the socio-cultural context of the migrants. After the pioneer detailed anthropological work done by J. Breman in the 
1990s in South Gujarat, hardly any studies were undertaken to understand the plight of migrants, their coping mechanisms, adversarial settings in which they work, their earnings, indebtedness, etc. Breman's ethnographic inquiry focussed on sugarcane harvesters, many of whom came to South Gujarat from neighbouring districts of Maharashtra state. With time, people in large number from the Dangs district in Gujarat began to seasonally migrate to sugarcane growing region as harvesters according to some Non-Governmental Organisations (NGOs) working in the region. They began to replace the Maharashtrian labour.

During informal discussions with NGO workers, we learnt that with the expansion of canal network in South Gujarat and with large-scale cultivation of sugarcane in the region, people from Dangs have been migrating every year to sugarcane farms. However, the official statistics on the district compiled and published in recent years do not reflect or acknowledge the seasonal exodus of people while discussing the distribution of workers by industry or activity or sources of their income (see District Census Handbook 2011; The District Human Development Report on the Dangs 2015). We therefore decided in 2017-2018 to undertake a study of the Dangi migrants with the objectives to estimate the magnitude of seasonal migration from the district; to understand the process of migration and factors that compel people to migrate; and to estimate their earnings from sugarcane cutting and other activities and whether the income is able to lift or further trap the migrants in poverty. A comparison of earnings and living conditions of seasonal migrants with that of non-migrants from the same area based on our survey data is a focus of another paper.

\section{Study area and methodology}

Dangs district is the smallest district in Gujarat in terms of population, with two census towns and one urban notified area and 308 villages. According to 2011 Census, the district's total population was 2.28 lakh, of which just $11 \%$ lived in urban areas. Nearly $95 \%$ population of the district is tribal. Until recently Dangs had no administrative subdivisions as blocks or talukas; it was only in 2013 the district was divided into three talukas-Ahwa, where the district headquarter is located, Waghai and Subir. The district is essentially a mountainous tract with dense forests which occupy 53\% of its total area. Although Dangs receives nearly 100 inches of rain in three months, because of its hilly terrain, the rainwater drains off. There are virtually no irrigation facilities, and so only rain-fed agriculture is possible on small parcels of land. As a result, every year a large number of people migrate mainly to work on sugarcane farms, a phenomenon observed and studied by Breman in the mid-1970s (Breman 1978).

We decided to randomly select $10 \%$ of total villages in the Dangs district for the study. Since Dangs district is divided into three blocks with its 308 villages nearly equally distributed between the three blocks, we selected an equal number of villages from each block. The goal of sampling design was to have, as far as possible, a self-weighing random sample. We used households as the primary sampling unit to select the villages in each block, and from each village, 30 households were selected after complete houselisting and by using the random start and equal interval. Thus, a total of 990 households formed the sample size of the study. We were able to contact and interview members of 979 households (99\%). 
Data were collected during the months of May-June 2017 when the seasonal migrants were back in their villages of origin. Besides interviewing the adult members of the households, we also interviewed a few key informants in the villages and the labour contractors (or mukadams). During November 2017, we also visited a few sugarcane farms or the workplace and temporary resident sites of the migrants from Dangs and held in depth interviews with some migrants at place of work.

For the field work, half of the investigators recruited were college-educated local youth from the Dangs district. This was necessary because they spoke the local dialects and we could pair them with other investigators who did not speak the local dialects. A consent form was prepared, and if the respondents were not able to sign, oral consent was obtained in the presence of another person. The respondents were informed that the information they provided would be treated as confidential and would not be shared with anyone but be used only for research purposes. They were free not to participate in the survey (either fully or partially) and were informed that non-participation would have no adverse consequences on their work or employment or on any entitlements due to them.

\section{Magnitude of migration}

As mentioned previously, one of the important objectives of our empirical study was to estimate the incidence of seasonal migration out of the Dangs every year. During the houselisting of the 33 villages, a question was asked whether any member(s) of the household had migrated for an extended period of time during 2015-2016 and 2016-2017 or two years preceding the survey. In response, $41.7 \%$ of households reported that some member of their family had migrated to work elsewhere in the previous years. Since our survey took place in the slack season (i.e. after sugarcane harvesting had ended and migrants had returned to their homes), it was possible to collect information and avoid logistical problems due to the non-availability of migrants. Since ours was a representative sample of the whole district, it means that of the nearly 44,000 rural households of Dangs district (according to 2011 Census), at least 18,000 households depended on seasonal migration for livelihood. In other words, from two out of five households one or more members migrated every year out of Dangs for employment.

Although during houselisting, nearly $42 \%$ of the households reported that some members of their households had migrated during the previous two years, during the detailed survey of 979 households, 348 households or $35.5 \%$ reported that one or more members had migrated in the previous season for work. The demographic profile of the people who migrated for work is presented in Table 1. The data are presented separately for the three blocks, since there are sizeable inter-block or taluka differences in the migration pattern.

As shown in Table 1, almost $80 \%$ of the migrants from our sample households reported that they worked as harvesters in sugarcane farms. They travelled from the Dangs to sugarcane farms located in Surat, Navsari and Valsad districts. The remaining 20\% either travelled elsewhere in Gujarat for casual labour, or to Maharashtra, often as labourers in vineyards or onion farms in the Nasik region. Some worked as woodcutters. These migrants tended to migrate for shorter durations (2-4 months) and generally went as couples, leaving their children behind. Some even migrated twice a year, for 2-4 months each time. Those who go to sugarcane farms as harvesters are away for about 175-180 days in year (nearly six to 7 months). They leave their villages soon after the Dashehra festival in October and return after completing the harvesting work sometime in April or early May. 


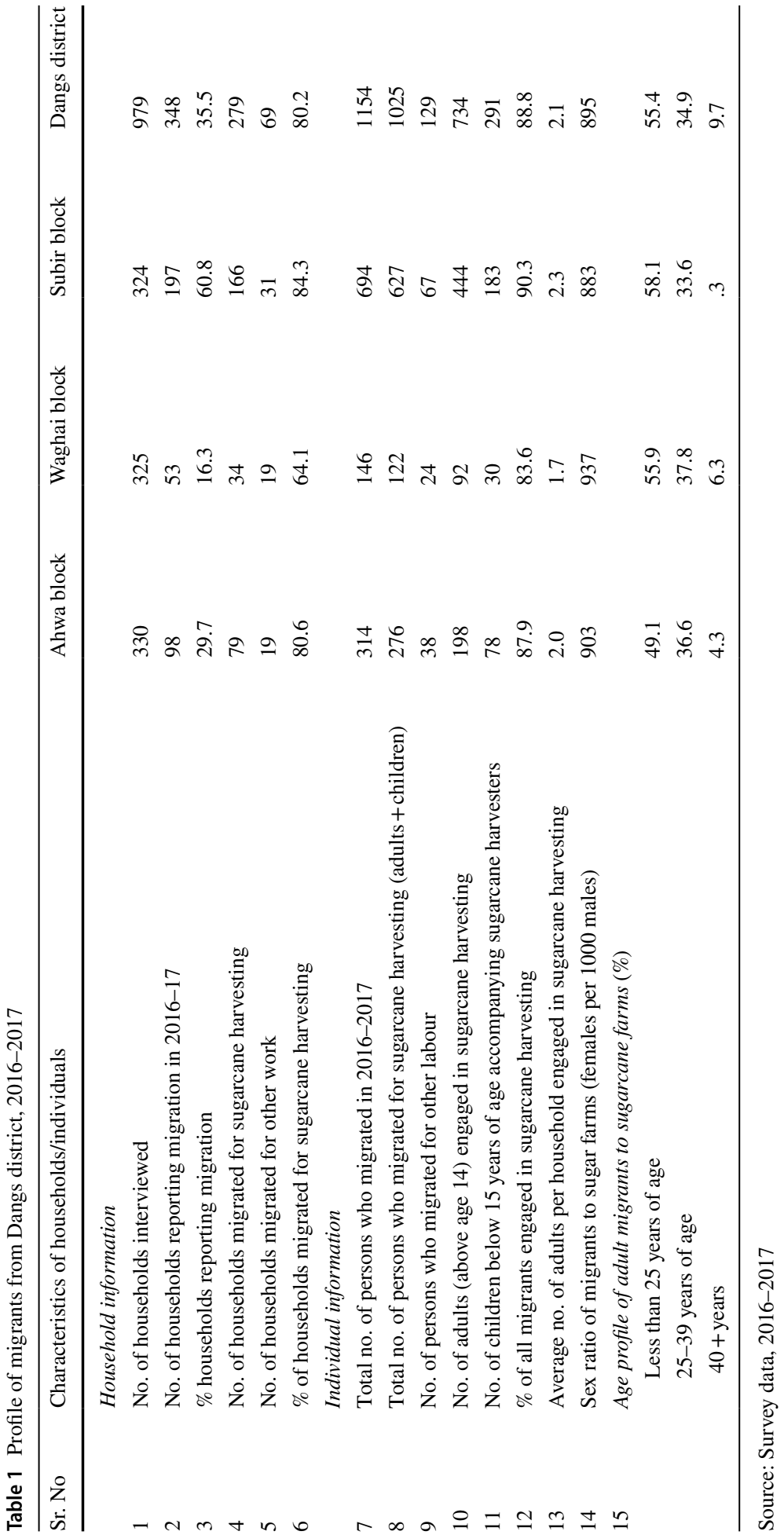




\section{Age profile of migrants}

Migrants to sugar farms are hired as a pair, known as a koyta. ${ }^{1}$ Koytas usually comprise of a husband and a wife. Occasionally, if a spouse is not available, then another person from the family (such as son, daughter or brother) joins the koyta. Failing that, the gang leader, known as the mukadam, may pair two individuals. On average, each migrant household sent 2.1 adult members to sugarcane farms. Since sugarcane harvesters are away from their villages for about 6-7 months, many couples brought their children along, which explain the presence of 291 or nearly $28 \%$ of children under age 15 who accompanied their parents on the sugarcane farms. ${ }^{2}$ Somewhat older children tend to look after the younger children if there is no one to look after them in the village, or if they are not enrolled in residential schools. They helped parents cut sugarcane as substitute workers, while their parents rested for a while. However, since these children were not part of koyta, they were not paid by the sugar factory for the work. They also helped their parents tie the top green blades of sugarcane plant (known as chimdi in Gujarati) bundles that are sold to farmers as feed for their cattle.

As shown in Table 1, nearly $90 \%$ of the sugar cutters were younger than 40 years of age, and two-thirds were below age 25. Given the strenuous work and long hours that this work involves, sugarcane harvesting is generally restricted to the young. As they age, these individuals become less likely to migrate to sugarcane farms and instead remain in their village and engage in animal husbandry and agricultural activities.

Women appear to provide an almost equal amount of effort in sugarcane cutting, as suggested by the sex ratio of the migrant workers. The established practice of hiring husband-wife team as koyta is partly responsible for the fact that women accompany men to the sugarcane farms and are equal partners in the work and wages. However, in addition to working along with men on the sugarcane farms, women are almost solely responsible for daily household chores of cooking, and cleaning as well as looking after children. Women spend their morning hours cooking and fetching water and arrive on the farm about an hour after the men have started work. They bring with them the daily meal for the family. They also bring along their small children to the farm. Thus, women face a double or triple burden.

\section{Inter-taluka variations in migration}

As evident in Table 1, there were large inter-taluka differences in the \% of households that were involved in sugar harvesting (with Subir block reporting the highest and Waghai reporting the lowest percentage). Three out of five enumerated households in Subir taluka, which is relatively more backward than the other two talukas, reported out-migration in the previous year. In fact, in several of the villages we interviewed in Subir, more than $75 \%$ of the households reported out-migration of adult men and women. Since many take their children with them, the houses are either locked up for several months or have aged parents during April to October. Overall seasonal migration from Waghai taluka is low compared

\footnotetext{
1 Sugarcane is harvested using a tool known as koyta, a word in Marathi language. However, the term in Gujarat has come to mean a pair of workers.

2 The tribal men and women from the Dangs marry quite early and by the time they are 25 years of age; many have at least two children. In our survey, of the 291 children who accompanied their parents, nearly $60 \%$ of them were under five years of age.
} 
to the other two talukas, partly because it is a better developed block with more employment opportunities within the taluka.

\section{Migration process}

Given that these workers migrate for a 6-7 month stretch at a time, they naturally tend to prepare for it in advance. The migration process described here is based on a series of questions asked to all the respondents and in depth interviews of the labour contractors. Soon after the harvesting season, when workers are back in their villages, recruiting agents of various sugar factories visit the taluka headquarters in Dangs and convene meetings of brokers or mukadams to know how many koytas each can supply. The mukadam contacts the persons who had been members of his gang in the previous season and with whom he has had no problems. He negotiates with them the amount asked as advance by each potential worker and gives the money with an explicit understanding that the amount will be deducted from the earnings at the end of the season with additional half of the advance amount as interest. ${ }^{3}$ Workers are free in their choice of the mukadam and join the team of the one who can offer larger amount as credit. However, we learnt that most people prefer to be part of the team of familiar people-both co-workers and mukadam.

The sugar factory arranges transportation to bring the koytas to pre-assigned places near the sugarcane fields. About 5 or 6 koytas travel in one lorry. They typically carry with them a sufficient supply of grains (nagli, rice, urad and tuver (lentils)) to last the whole season, utensils, bedding and clothes. They also carry firewood that they have collected from the forest over several weeks during their stay in the villages and also bring construction materials such as bamboo for their temporary housing (danga) erected at the worksite. The sugar factory gives them tarpaulin sheets to make the roofs. The journey from their village to the sugarcane fields usually takes about $4-5 \mathrm{~h}$ since the sugarcane farms are located in the neighbouring districts. The koytas are charged a small amount as transportation cost. This is deducted from their final payment at the end of the season.

Since they have been migrating year after year, the koytas seem to be able to estimate their food and fuel needs for the season quite accurately. Almost all of them reported that they had taken enough fuel wood with them in the previous season and occasionally supplemented it with dry sugarcane stalks. No one reported buying fuel from the local market. The staple food of the Dangi tribal consists of nagli (coarse millet), rice and urad (black gram) or tuver dal. They tend to bring these items with them and buy condiments, cooking oil and vegetables from the shops in the area. In fact, $58 \%$ of the koytas reported that there was a shop set up within the danga (the cluster where migrants stay) and another $25 \%$ reported that a shop was available within the vicinity of their danga. Within the danga, the shop is generally set up by the mukadam and managed by him with support from wife or a relative.

\footnotetext{
${ }^{3}$ Mukadams, whom we contacted, reported that they also borrow money from money lenders and others on the same terms. It is their own savings, when ploughed in the transaction, fetches them handsome interest and is their earning.
} 


\section{Living and working conditions}

The sugarcane farmers allot some space near their farms to the harvesters to set up their danga. The average danga can accommodate 20-30 families. ${ }^{4}$ The dangas are typically a little distance away from the main village. When asked whether the koytas faced any difficulty setting up their shelter, $42 \%$ of the respondents reported that had no problem, but nearly half of them felt that the earth tended to be mushy or slushy and so it was difficult to set up their shelter. This is largely because the koytas arrive soon after the monsoon ends and because South Gujarat tends to receive heavy rainfall; the land retains moisture for a long time.

Nearly $40 \%$ of respondents reported that water was available to them in their danga, typically through a hand pump in the area. But a quarter reported that the water source was a considerable distance away from their danga. Some koytas reported that they bathed and washed their clothes in the canals in their areas. At some places, makeshift private bathing space is created with the help of grass and bamboo sticks. Nearly a third felt that the villagers were not very cooperative or helpful in providing water to the koytas. Nearly $97 \%$ of koytas - both men and women-reported that they defecate in the open fields. The Swach Bharat Abhiyan has yet to reach these places. The temporariness of the danga is a real barrier to the provision of basic minimum services as described by other researchers as well (see Desai and Rami 2016; Mosse et al. 2002). At very few places, one electric post, a hand pump and a toilet have been constructed under the Swachchh Bharat Abhiyan, but elsewhere even these minimal facilities are missing (see Bansole 2013).

One of the frequently reported problems by the koytas was the lack of electricity. Sometimes the nearby village provided one electrical post for the entire area, but the individual shelters had no electricity. Some koytas also complained about the menace of mosquitoes and the unhealthy (and filthy) surroundings. Sometimes the land assigned to the koytas tended to be near garbage dumps or similar unhygienic places. Twelve out of 348 families reported that there was no tree cover near the dangas to provide any shade. Also, there were no trees on the edges of the sugarcane farms to provide shade to the harvesters when they take their lunch break. ${ }^{5}$ Small children wander around in the farms on hot sunny days and infants are kept under a makeshift cloth canopy created in the sugarcane field. Unlike in the earlier times, the koytas now do not have to change their shelter often during the season. ${ }^{6}$

The koytas generally worked between 10 and $12 \mathrm{~h}$ per day. They start work around 7 in the morning and harvest the cane until twilight. Their lunch break is usually one hour. Women join their partners roughly around $8 \mathrm{am}$, after attending to household chores. The koytas also have to work at night if the trucks to load sugar cane arrive at night. Generally, women are not called to load the truck at night. The average truck has a capacity of 12-14 tons of sugarcane and can take three to four hours to load.

\footnotetext{
${ }^{4}$ Where more space is available, the dangas tend to be larger and can accommodate 50-60 koytas. These could constitute two or three teams, supervised by one able mukadam or more than one mukadam.

5 When asked why there are no trees even on the edge of their farms, the owners of sugarcane farms replied that planting trees would 'waste' their precious farm land, because sugarcane cannot grow under the trees. Every sq. meter of land is considered valuable and used for growing the lucrative sugarcane.

${ }^{6}$ Breman, for example, in his study undertaken in the mid-1970s, reported that the koytas had to shift their shelter 10-12 times during the harvesting season (Breman 1978).
} 
The koytas use a sharp hatchet that allows them to cut two or three stalks of sugarcane in one stroke. Only $7.5 \%$ of men and $4 \%$ of women reported suffering an injury while cutting sugarcane. If the injury is major and serious, the mukadam arranges to take the koyta to the clinics run by the sugar factory. The treatment is free and borne by the factory. However, for minor health problems such as fever, diarrhoea, headache or body ache, the koytas have to bear the expenses themselves. If he owns a shop within the danga, the mukadam often dispenses medication for common ailments. It is equally likely that some minor ailments are ignored.

Given the long duration of 6-7 months that the koytas work in the sugarcane fields, some do return to their villages for short visits to see their children or aged parents whom they have left behind. Holi is also an important festival for the tribal population, and most koytas go home for a few days. The sugar factories have recognised this, and we were informed that they allow five days of leave to the koytas during this time.

Dangs district is one of the most backward districts of Gujarat in terms of majority of the social and economic indicators. Given the mountainous terrain, limited agriculture, non-existent industrial activity and poor human development, the tribal have very limited livelihood options within the district. Although the district receives plenty of rainfall, the nature of soil, limited land for cultivation and ownership of small parcels of land have not been able to provide full-time employment year round to the inhabitants. On their small parcel of land, people cultivate food crops mainly for self-consumption. The livelihood options are further hindered due to poor literacy and skills of population. As a result, a large proportion of households send some members out to work in sugarcane farms or other such activities. They have virtually no other alternative livelihood options and alternate living between two places every year and become footloose individuals with a sense of not belonging to either place.

\section{Wages and income of sugar harvesters}

When the respondents were asked in the survey on the wages paid to the sugarcane harvesters, we realized that they had practically no idea about the daily rate at which they earned wages. This is because the payment for sugarcane harvesting is not decided on the basis of an individual's quantum of work, but the total payable amount is calculated for the quantum of sugarcane harvested by the whole team during the entire harvesting season. The harvesters accepted the consolidated net amount they received at the end of the season. A few of them knew the per ton payment for sugarcane harvesting fixed by the sugar factory in consultation with the state government. Very few knew the total tonnage of sugarcane the team of 15-20 koytas had cut and loaded during the entire season. At the end of the season, the sugar factory pays full amount at the rate decided in advance for the total sugarcane harvested by the team of a mukadam, who in turn distributes it equally to the team members. ${ }^{7}$ So in addition to trying to find out from the workers how much each koyta received at the end of the season, we also interviewed a few mukadams and asked them detailed questions on the total quantum of sugarcane harvested by their team of koytas during the previous season, at what per ton the sugar factory paid for harvested sugarcane, and the total amount received and distributed to the workers.

\footnotetext{
${ }^{7}$ Generally speaking each mukadam is in charge of 15-20 koytas or 30-40 workers.
} 
Since we were also interested in arriving at an estimate of the total annual income of the seasonal migrants, we included in the questionnaire the value of the food or non-food crops that they grew and sold, if any, when they were back in their villages. They were also asked whether in addition to sugar harvesting, they worked elsewhere as wage labourers and for how long and their earnings from such activities. We also inquired about their income from selling the sugarcane blades or chimdi. We collected information on loans they had taken before and during the harvesting season, the interest rate charged and deducted. We also found out from the mukadams and other sources the amount the factory deducts for various services and goods, such as transportation, health services, grains and tarpaulin, it provides to the koytas. ${ }^{8}$

\section{Income from wage labour}

In order to estimate how much each sugar cane harvester team of two should be paid at the end of the sugarcane cutting season, mukadam keeps an account of the amount that he has lent to each koyta, number of days they remain absent, and dues to the sugar factory for jowar, tarpaulin and use of transport facility. These vary between workers and cause variations in their final take-home payment even though the rate of payment for sugarcane cutting is uniform for all. The mukadam deducts the amount borrowed from him while settling each worker's payments. In addition, he charges and deducts the interest on the amount at $50 \%$. Regardless of the duration for which money is borrowed, the practice is to charge half of the amount borrowed as interest. Some estimated amount is also deducted for the number of days the koytas remain absent from work beyond the stipulated number of days of leave granted to them. ${ }^{9}$ In addition, the factory deducts the cost of jowar that the koytas buy; the amount bought varies between koytas. If any koyta has bought other items such as tarpaulin for their huts, the cost of it is also adjusted against the final payment.

Typically, the sugar factory transfers the money to the mukadams, who in turn, after making all the adjustments, distribute it to the koytas. Although we asked the respondents the amount they took home after the harvesting season was over, it was difficult to tabulate the information of each worker to arrive at meaningful daily wage rate for working as sugarcane harvester. Majority of them could not provide information on the various deductions.

\section{Estimate of earnings based on information of mukadams}

Therefore, we obtained information from the few mukadams we interviewed, on the total amount of sugarcane that was harvested by each mukadam's team of koytas in the entire season and the price per ton that was paid by the factory to be distributed between the koytas. Information was also collected from each mukadam on the number of koytas that

\footnotetext{
8 Some of the services offered are optional, and workers may decide not to avail any or all. For example, some workers may decide not to take any jowar, millet that the sugar factory offers at subsidized rate, since it is not their staple food.

${ }^{9}$ On an average, the workers are allowed five days of leave in the season (to visit their places of origin), in addition to one day in a week to attend to their household chores such as washing and going to market for small purchases. Some of the mukadams, we interviewed, reported that if any worker remains away from work for more days than the number of days permitted, Rs. 100 per day per person is deducted. However, no written records are maintained and the system operates on word of mouth.
} 


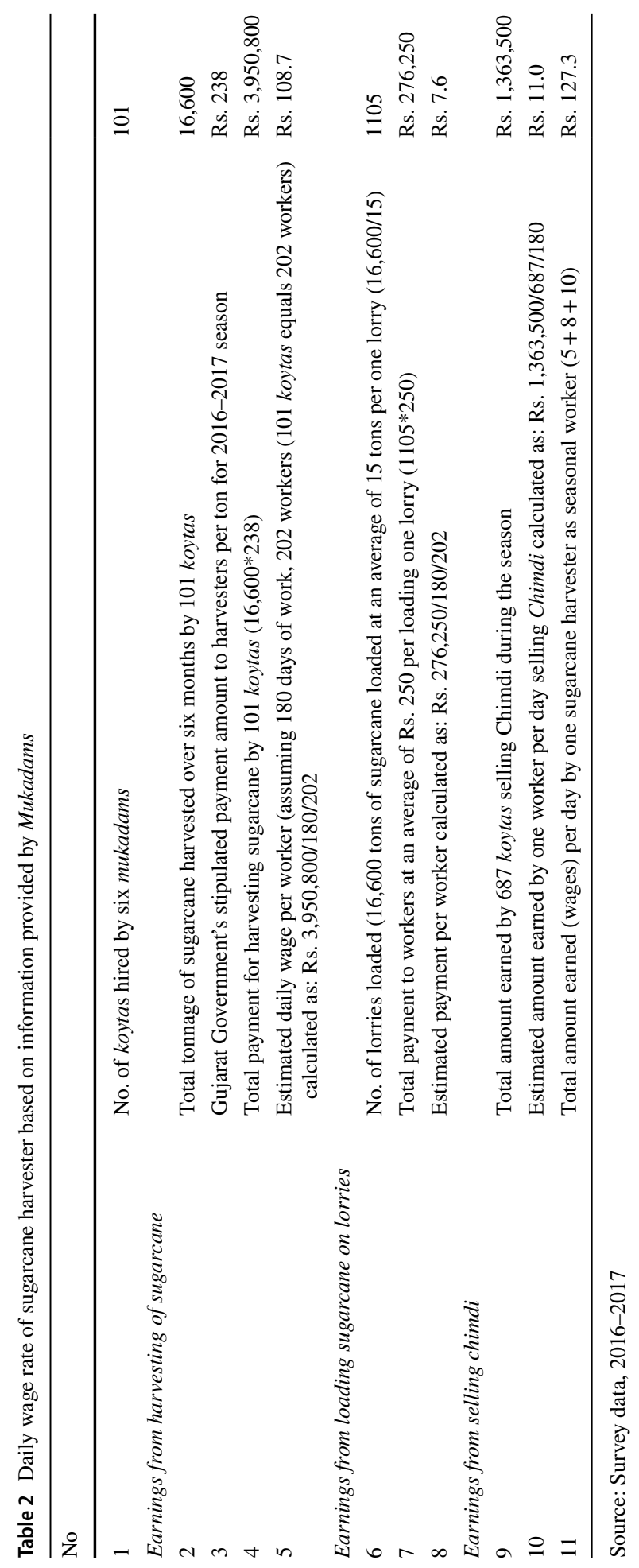


worked under him and the average number of days they worked during the season. Using these pieces of information, we arrived at the figure of daily wage rate per worker.

Based on the detailed information provided by six of the nine mukadams we interviewed on the amount of sugarcane harvested by their team during the entire season, we calculated that a total of 16,600 tons of sugarcane was harvested by the team of 101 koytas. There was practically no variation in output between mukadams. The payment to harvesters per ton was decided at Rs. 238 by the Gujarat Government for the year 2016-2017 in consultation with sugar factories. As shown in Table 2, this worked out as Rs. 108.7 per worker per day as daily wage rate or earning for harvesting sugarcane. ${ }^{10}$

However, in addition, the workers are also paid some extra amount for loading sugarcane on the lorries. For loading one lorry, which is supposed to be loaded with 12-14 tons of sugarcane, payment at the rate of Rs. 200-300 per lorry is made to the workers. The rate varies depending on the distance that the workers have to walk to the lorry. When the lorry is parked near the sugarcane bundles, payment is less, but as the distance increases, the payment is higher and goes up to Rs. 300 per lorry. The lorry owners pay this amount to the mukadams, , but it was difficult to ascertain whether any, partial or full amount is transferred to the koytas. However, we have assumed that the mukadams included it while making the payment to the koytas. As shown in Table 2, it worked out payment of Rs. 7.6 per worker per day.

\section{Income from selling sugarcane blades or chimdi}

Nearly $70 \%$ of the respondents from the 979 household surveyed were able to provide information on the extra income they could earn from selling the green blades from the sugarcane, which is used as fodder for cattle. The selling price of one bundle of 8-10 blades varies on the availability, season, demand and quality of the blades, but ranges between 70 paise and one rupee. There is an impression among the sugar factory managers, other officials and farm owners that the sugarcane harvesters make some extra income which is quite substantial and important to meet some of their daily needs, while they live in the dangas. The impression is also created because some koytas do report earnings anywhere between Rs. 6,000 and 12,000 selling Chimdi during the whole season.

We asked each migrant worker household to report approximately the amount they earned selling Chimdi during the last season of 2016-2017. Based on the information, we calculated the total amount they earned per day per worker as shown in Table 2. The daily earning of one harvester worked out to be Rs. 11/- or Rs. 22 per team. ${ }^{11}$ The work put in by children in tying chimdi into bundles does not fetch any remuneration because they help their parents. However, the hype that the extra earning from selling chimdi is quite substantial and remunerative and provides much needed financial support to the sugarcane harvesters needs to be challenged.

\footnotetext{
${ }^{10}$ According to some officials of the sugar factory, one koyta should on an average harvest one ton of sugarcane a day. As per the information provided by the mukadams, the daily average of their koytas was about $900 \mathrm{~kg}$. or 0.9 ton. Using that as an estimate, the payment to two individuals would work out $(0.9 * \mathrm{Rs}$. $238=$ Rs. 214) or Rs. 107 per person per day. The figure is almost the same as worked out from the actual amount of sugarcane harvested.

11 Since the harvesters bring grains and staple food, firewood and other essential items from home to last the whole season, Rs. 22 per day is spent on buying vegetables, oil, condiments and snacks for children.
} 
When this additional amount earned by the workers (by selling chimdi and loading the lorries) while working at sugarcane farms is added to their daily wage rate, it goes up to Rs. 127.3 per day as shown in Table 2. We have, however, not discounted for the likelihood that when sugar factories are overloaded with sugarcane or when the factory has to shut down crushing sugarcane because of technical malfunction or for cleanup operation, the koytas are instructed to stop harvesting sugarcane. During such times, they lose even the minimum piece rate wage due to them.

During the household survey, all the respondents were also asked details of their earnings from various sources and amount borrowed and interest paid to the mukadam, who is the typical lender since men do not share such information with womenfolk. At the end of the harvest season, payments are typically made to the male member of the koyta team and so for such households, we did not have all the information on gross and net earnings. While the information provided by the mukadams is based on objective criteria, verifiable with the records from the sugar factories, it is important to cross check with the information from the respondents. Based on the reporting of some male members, randomly selected from the surveyed households, we compiled the detailed data on earnings from sugarcane harvesting. The average daily wage rate for sugarcane harvesting reported by the male respondents worked out to be Rs. 127. The harvesters did not know whether it included payment for loading the lorries, but presumably it is added to what they received from the mukadam. According to our calculations based on reporting of the mukadams, the average payment to one harvester was Rs. 116 for sugarcane harvesting and loading work, a figure slightly lower than what the few randomly selected respondents reported. It is important to know that the mukadams are from the same area, belong to the same tribal group and worked as sugarcane harvesters for several years before being picked up by the sugar factories and promoted as mukadams. The koytas trust them, and some of them are even closely related to the mukadams. During our in depth interactions with koytas, we did not come across any instance of breach of trust between the mukadams and the harvesters.

The daily wage rate in Gujarat for agricultural labourer according to Government of Gujarat's Labour commissionerate in April 2017 was Rs. 305.6. The sugarcane harvesters, at best, earned Rs. 127.3 per day in the last season according to our detailed calculations or less than half of the mandated minimum wage rate for agricultural labourer. They earn not even the basic daily wage without any special allowance fixed for unskilled work by Gujarat government at Rs. 276 or minimum daily wage rate under MGNREGA (Mahatma Gandhi National Rural Employment Guarantee Act) of Rs. 202. According to a report of the Ministry of Rural Development, the real wages of both male and female agricultural workers of Gujarat in 2016-17 were worse than most major Indian states. Male workers received Rs. 223 per day, and female workers received Rs. 202 per day (Ministry of Rural Development 2017). The seasonal workers have no bargaining power against powerful lobbies or corporate sector operated industries. Sugar lobby, consisting of rich farmers, sugar factories, reportedly derives their clout from political connections and has succeeded in keeping the wages low.

\section{Other sources of earning}

We sought information about the sources of income during the rest of the year when the migrants are back in their villages. The households, who owned some land (nearly $70 \%$ of the migrant households owning some land), tended to spend a major part of their time during summer and rainy months cultivating it. However, the size of land tended to be quite 
small and without any irrigation facilities the families grew an assortment of food grains mainly for self-consumption. In fact, less than $3 \%$ of households had some surplus of rice and nagli that they sold in the market.

We also asked every respondent whether and for how many days they worked in MGNREGA for wages. ${ }^{12}$ Only $4 \%$ of respondents aged $15-59$ reported that they had on an average worked for 7 days in the MGNREGA during 2016-2017. It must be conceded that in relation to the amount disbursed by the district on the scheme, the reported figures appear too low and it is possible that the respondents did not correctly report or did not view the programme as providing sustainable livelihood security or employment.

To a question on the major source of income, $82.5 \%$ of the migrant households reported earnings from sugarcane harvesting as their major source of income and nine\% reported agriculture or cultivation as their major source of income. Evidently, there are hardly any opportunities for other work available in the villages of the Dangs during the five-six months that the migrants are back in their villages. Thus, seasonal migration, mainly to sugarcane farms, appears to be the only coping mechanism for survival for more than a third of the households from the Dangs district. As migrants, they appear trapped in poverty, and even if they are not 'bonded', they have no choice, resources, skills, education or other support to escape from going year after year and generation after generation to work as sugarcane harvesters (see Breman 2007, 2008).

\section{Settlement of debt and indebtedness}

Based on the information on earnings during sugarcane harvesting, each worker would earn about Rs. 23,000 (rounded figure) during his/her stay at the sugarcane farm for nearly six months. ${ }^{13}$ As koyta or a team of two family members, their take-home gross income for six months would be Rs. 46,000. However, majority of them borrow money from mukadams in advance and pay interest on that amount, which are deducted by the mukadams while settling their payments. Therefore, the net take-home amount of koytas is considerably reduced.

Based on the reported amount borrowed from mukadams, we noted that, on an average, one couple had borrowed nearly Rs. 15,200 and paid half that amount or Rs. 7600 as interest to the mukadam (Visaria and Joshi 2018). The net take-home amount for koyta or two earners was thus reduced from Rs. 46,000 to Rs. 23,200 (after mukadam deducts Rs. 22,800 as principal plus interest) or just about half. Since this is a receivable amount of two members of the team, each person's net take-home wages for six months would be half of it or Rs. 11,600. Since not all workers borrow the same amount, the deductions from their earnings would vary. Those who borrow large amounts as advance return home with very little in hand and end up having to borrow almost immediately from mukadams and thereby committing to work in the next season and trapped in indebtedness.

\footnotetext{
12 MGNREGA, launched in 2005, is a measure that aims to guarantee the right to work or to enhance livelihood security in rural areas by providing at least 100 days of wage employment to adult members.

13 Based on the estimates presented in Table 2, a typical one sugarcane harvester would earn during the entire season about Rs. 19,500 for sugarcane harvesting, Rs. 2000 for selling chimdi and Rs. 1500 for loading sugarcane on the lorries; a total of Rs. 23,000 (figures are rounded) for work over six months or 180 days. The pair or koyta would earn Rs. 46,000.
} 


\section{Vicious cycle of poverty}

In order to understand why seasonal migrants, whether they are employed as sugarcane harvesters or brick kiln workers or salt pan workers or even construction workers, are trapped in the vicious cycle of poverty, it is important to understand their recruitment process. Most of these workers living in rural areas, belonging to disadvantaged social groups, are recruited by mukadams or labour contractors as Jodi workers or as a pair (see for example, Roy and Kunduri 2018; Guerin et al. 2007; Joshi and Khandelwal 2009; Andharia 2011). These brokers supply the required number of workers at the right time with the least cost. As far as the sugar industry is concerned, it is assured cheap, reliable and yet temporary workers, towards whom the industry has no responsibility or accountability. If the sugar factories institute any minor welfare measures, they do so as a largesse and charity and not as workers' rights. The factories are able to totally bypass the enforcement of minimum wages rule, since sugarcane harvesters are not employed by the factories.

Sugarcane harvesters are recruited anew every year for half a year or for the duration of the harvesting season, and sugar factories have no responsibility for their employment or survival beyond the period when they return to their villages. This arrangement is to the advantage of the sugar factories because their obligations to the sugarcane cutters are absolute minimum. It is the mukadams who recruit and bring the workers to the working site, ensuring that sugarcane is cut and loaded without any hassle. This practice started in the 1960s when seasonal migrants came from Maharashtra to harvest sugarcane continues even today (Jugale 2012; Breman 2010; Rose 2018).

Further, the sugarcane cutters in south Gujarat are not local workers, and they are brought from the Dangs and other tribal districts. As stated by Breman, this preference for hiring 'outsiders' apparently gives an edge to the sugar factories and 'command a pliable and vulnerable labour force which by their status as aliens and transients has ...forfeited bargaining power' (Breman 2009).

Back in their villages, the workers spend their time in growing some food for subsistence, repair their houses, collect firewood from the forest for their temporary stay at sugarcane farms and take part in some festivities. There are virtually no employment opportunities within their villages. They live on money earned or borrowed in advance against payment through labour later in the year. There is no way out of the poverty trap because they lack physical and social capital such as education or skills or networks. The complex system created to recruit the tribal as temporary workers, payment to them on the basis of piece rate at the end of the harvesting season, keeping them isolated in dangas away from the villages, depriving their children of schooling, has huge disempowering effect on the people. The circularity of migration has continued for two or three generations.

\section{What is the way out?}

Is there a way out? Many believe that migration has the potential to contribute to development of a nation. However, as our data have shown, migration is associated with unacceptable treatment of some of the most vulnerable people in the labour market, and therefore, it needs a major policy initiative. The Indian government must develop a comprehensive migration policy that will address the miserable conditions in which both long-term and seasonal migrants live, work and are exploited by paying them less than even bare minimum wages. The policy must advocate decent work opportunities 
for all migrant workers, respect their fundamental rights, recognize their contribution and develop an understanding of the communities from which they come and places where they work. Also, clear rules and regulations have to be formulated for implementation. The lockdowns due to COVID-19 pandemic have not only brought home the magnitude of migrant workforce but also its vulnerabilities.

Along with a migration policy, attention must be paid to creating livelihood opportunities within the districts from where migrants travel in search of work, through MGNREGA or other similar schemes. These may help some people to find work within or near their place of residence. Instead of digging ditches and moving earth from one place to another, programmes such as deepening farm ponds, building Anganwadi centres, repairing schools, individual toilets and vermi compost pits can improve village infrastructure, provide employment, create community assets and enhance education and skills to the next generation. Such measures hopefully will lift them from the poverty trap.

In Dangs, many tribal families own small plots of land on which they grow food for self-consumption. In addition to growing food, they can be helped to grow cash crops to increase their income from small parcels of land. For example, an NGO [Bharatiya Agro Industries Foundation (BAIF)] has helped a few farmers in the Dangs to grow cashew nut trees with success. Similarly, an experiment with mushroom cultivation in Dangs holds a lot of promise. Along with helping people to diversify their agricultural practices, processing of produce, establishing backward and forward linkages and ensuring market for the products must be given priority to enable the tribal to reap full benefits of the inputs needed to grow alternative income enhancing crops. It may decrease the need for all adult members from a family to migrate year after year in search of work.

The forest of Dangs is rich in teak wood and bamboo. These valuable resources are taken away by big industries, often illegally, without concern about the problems created due to deforestation. Urgent attention needs to be paid to stop this exploitation. Equally important is to ensure that when old trees need to be cut or when forest produce is collected, they are semi-processed by the local population in the area and thereby provide employment to the local people. The administration at all levels has to be vigilant and with the help of NGOs, and others train the villagers to preserve their resources and at the same time create employment opportunities for them.

Health and education of children of migrant families need urgent, concerted and innovative solutions. We have to have a resolute policy to lift the children out of the poverty trap. On a small scale, a successful effort has been made by setting up boarding houses or hostels in the villages for school going children of seasonally migrant families. The children are provided shelter and food, while they attend local village school. These hostels function for the duration that the parents are away. Children are united with parents upon their return from work. Equally importantly, the health services in remote areas cannot be neglected. Children and women, in particular, become victims of the non-functioning health system. Even in the medium term, we cannot afford to sacrifice social programmes at the altar of industrial growth of a state.

Funding The research is funded by Aware Foundation, UK, and American India Foundation, New Delhi.

\section{Compliance with ethical standards}

Conflicts of interest The authors declare that they have no conflict of interest. 
Availability of data and material Data are available with authors.

\section{References}

Andharia PB (2011) Salt pan workers in Gujarat: examining the need for a special legislation, Doi: https:// doi.org/10.2139/ssrn.1922287.

Ashok S, Thomas N (2014) A study on issues of inter-state migrant labourers in India. Int J Sci Eng Res 5(7):91-94

Bansole P (2013) Seasonal migrants and quality of life: Sugarcane cutter migrants at destination and source. Artha Vijnana 55(4):366-381

Breman J (1978) Seasonal migration and co-operative capitalism: Crushing of cane and of labour by sugar factories of Bardoli. Econ Polit Weekly 13(31-33):1319-1360

Breman J (1996) Footloose labour: working in the indian informal economy. Cambridge University Press, Cambridge

Breman J (2007) Labour bondage in West India: from past to present. Oxford University Press, New Delhi

Breman J (2008) “On labour bondage, old and new', The. Indian J Labour Econ 51(1):83-90

Breman J (2009) "The great transformation in the Setting of Asia", address delivered on the occasion of the award of the degree Doctor Honoris Causa on the 57th Anniversary of the International Institute of Social Studies. The Netherlands, The Hague

Breman J (2010) "Neo-Bondage: A field-based account. Int Labor Working Class History 78:48-62

Census of India (2011) Gujarat, Series-25, Part-XII-A, District Census Handbook: The Dangs, Village and Town Directory, 2014

Choudhury C (2007) https://ruralindiaonline.org/articles/the-sugarcane-cutters-bitter-harvest. Accessed 8 October 2018

Desai ZK, Rami G (2016) Socio-economic conditions of workers in Gandevi sugar industry: with special reference to cutting and loading labour. J Inf Knowl Res Humanit Soc Sci 4(1):223-227

Deshingkar P, Akter S (2009) Migration and Human Development in India, human development research paper 2009/13, United Nations Development Programme

Deshingkar P, Start D (2003) "Seasonal migration for livelihoods in india: coping, accumulation and exclusion", Working Paper 220, Overseas Development Institute, London

Government of Gujarat (2015) District Human Development Report: The Dangs, Gujarat social infrastructure development society (GSIDS) General Administration Department (Planning), Gandhinagar

Guérin I, Augendra B, Parthasarthy, Venkatasubramanian G (2007) Labour in Brick Kilns: A Case Study in Chennai”, Econ Polit Weekly 42(7): 599-606

Joshi B, Khandelwal R (2009) Circular migration streams from southern Rajasthan: brick kiln work, work in textile markets, and ice cream vending. In: Deshingkar P, Farrington J (eds) Circular migration and multilocational livelihood strategies in rural India. Oxford University Press, New Delhi, pp 118-138

Jugale VB (2012) Migrant workers of sugar industry in Maharashtra. J Econ Soc Dev 8(1):15-24

Kesari K, Bhagat RB (2012) Temporary and seasonal migration: regional pattern, characteristics and associated factors. Econ Polit Weekly 47(4):81-88

Ministry of Rural Development (2017) "Report of the committee on alignment of national rural employment guarantee Act (NREGA) Wages with Minimum Agricultural Wages: July 2017”, New Delhi

Mosse D, Gupta S, Mehta M, Shah V, Rees J and The KRIBP Project Team (2002) Brokered Livelihoods: Debt, Labour Migration and Development in Tribal Western India', J Dev Stud 38(5): 59-87

National Sample Survey Organisation (NSSO) (2001) Migration in India 1999-2000, (55th round), New Delhi: Ministry of Statistics and Programme Implementation, Government of India

National Sample Survey Organisation (NSSO) (2010) Migration in India 2007-2008 (64th round), New Delhi: Ministry of Statistics and Programme Implementation, Government of India

Rao N (2005a) Power, culture and resources in gendered seasonal migrationfrom Santhal Parganas. In: Arya S, Roy A (eds) Poverty, gender and migration. Sage Publication, New Delhi

Rao N (2005b) Power, culture and resources in gendered seasonal migration from Santhal Parganas. In: Arya S, Roy A (eds) Poverty, gender and migration. Sage Publication, New Delhi

Rogaly B, Biswas J, Coppard D, Rafique A, Rana K, Sengupta A (2001) SeasonalMigration, social change and migrants rights, lessons from West Bengal. Econ Polit Weekly 36(49):4547-4559

Rogaly B, Coppard D, Ratique A, Rana K, Sengupta A, Biswas J (2002) Seasonal migration and welfare/ illfare in Eastern India: a social analysis. J Dev Stud 38(5):89-114

Rose A (2018) "The bonded sugarcane harvesters of South Gujarat”, The Wire, May 19, 2018 
Roy SN, Kunduri E (2018) "Migration to brick kilns in India: an APPRAISAL", New Delhi, Centre for Policy Research

Srivastva R, Sasikumar SK (2003) "An overview of migration in India, its impacts and key issues", paper presented at regional conference on Migration, Development and Pro-poor Choices in Asia at Dhaka, Bangladesh. http://www.eldis.org/vfile/upload/1/document/0903/Dhaka_cp_2.pdf. Accessed 15 Aug 2008

Visaria L, Joshi H (2018) Trapped: A Cycle of Poverty, Migration and Exploitation, Aware Foundation and American India Foundation, Ahmedabad

Publisher's Note Springer Nature remains neutral with regard to jurisdictional claims in published maps and institutional affiliations. 